\title{
Energy security problems at the regional level: situation analysis and main trends
}

Elena Smirnova*, and Sergey Senderov, Melentiev Energy Systems Institute of Siberian Branch of the Russian Academy of Sciences, Irkutsk, Russia

\begin{abstract}
The paper is devoted to the problem of assessing the state of energy security at the regional level, analysing the main trends and the scale of changes in the state of energy security in the regions of Russia. Regions of Russia with an unsatisfactory state of energy security have been identified, and the dynamics of changes in the state of energy security in all regions of Russia during the period from 2012 to 2016 are shown. Factors and reasons for the formation of negative and positive trends in this aspect were analysed.
\end{abstract}

\section{Introduction}

One of the most important activities to achieve and maintain the required level of energy security (ES) in Russia is monitoring and indicative analysis of ES. This is an essential component for the formation of control, analytical and, to some extent, coordination functions of state regulation in the field of providing ES. The tasks of monitoring the ES Russia and its regions are to identify the observed and expected processes, phenomena and parameters that determine the level and threats of energy security. At the same time, the identification process is based on a system of indicators that adequately describe the situation in one or another aspect of securing ES. Thus, the meaning and essence of monitoring and indicative analysis consist in displaying information on the degree of implementation of ES threats using an indicator system when comparing the numerical values of these indicators with their threshold values. In accordance with this, the ESI SB RAS has developed an information base for the justification and decision-making on ensuring the ES Russia and its regions. In addition to assessments related to one year, it is important to analyze the dynamic range of indicator values and their qualitative assessments in order to understand the direction of emerging trends with the provision of ES.

Energy security - the state of protection of citizens, society, the state, the economy from the threat of a deficit in providing their energy needs with economically accessible energy resources of acceptable quality, from threats of disrupting the continuity of energy supply $[1,2]$. In fact, it is about balancing the supply and demand of energy or the lack of deficit of energy balance in different conditions. To assess the state of the ES regions of Russia and, to identify emerging trends in this regard, it is necessary to monitor and analyze the state of domestic energy sector. Such an assessment can be performed in accordance with the methodology for monitoring the state of Russia's ES at the regional level, that is, on the

\footnotetext{
* Corresponding author: alenaink08@mail.ru
} 
basis of monitoring the most important indicators of the functioning of energy sector at a given point in time.

This paper presents materials that characterize the state of ES in the regions of Russia across all federal districts. Such estimates were obtained with the direct use, previously developed, of a methodology for monitoring the state of ES [3]. All regions are ranked according to the state of their ES. Studies conducted on different time scales $(2012,2016)$, allowed to assess the direction of the change in the situation with the provision of ES in the regions of Russia and the dynamics of these changes over the past five years.

A detailed analysis of the situation with the provision of ES requirements for each indicator is considered in this paper on the example of the Siberian Federal District.

Currently, the assessment of the state of the ES regions of the country [3,4] is based on the use of a system of indicators conditionally distributed across three interrelated blocks, Table 1 . The values of the indicators characterize the situation with the provision of ES in the region in the analyzed aspect. Separation of individual blocks is necessary to obtain an idea of the most important points of securing the ES regions. Each of the presented in Table 1 indicator has its own, previously expertly generated and justified, threshold values. It is the threshold values that determine the boundary of the assignment of the actual value of the indicator to a particular area of qualitative states.

Table 1. Composition of the most important indicators of regional energy security

\begin{tabular}{|c|}
\hline $\begin{array}{l}\text { 1. Block of production and resource provision of the fuel- } \\
\text { and energy supply system }\end{array}$ \\
\hline $\begin{array}{l}\text { 1.1. The ratio of the total available capacity of the region's power plants to the maximum } \\
\text { electric load of consumers on its territory. } \\
\text { 1.2. The ratio of the amount of available capacity of power plants and the capacity of inter- } \\
\text { system connections of the region with neighboring consumers to the maximum electric load on } \\
\text { its territory. } \\
\text { 1.3. Possibilities to meet the needs for primary energy from the region's own sources. }\end{array}$ \\
\hline $\begin{array}{l}\text { 2. The block of reliability of fuel and energy supply of the region } \\
\end{array}$ \\
\hline $\begin{array}{l}\text { 2.1. The share of the dominant resource in the total primary energy consumption in the region. } \\
\text { 2.2. The share of the largest power plant in the installed electric capacity of the region. } \\
\text { 2.3. The level of potential supply of demand for fuel in the conditions of a sharp cooling }(10 \% \\
\text { increase in consumption) in the region. }\end{array}$ \\
\hline $\begin{array}{l}\text { 3. Block of the state of the basic production assets of energy systems in the territory of the } \\
\text { region }\end{array}$ \\
\hline $\begin{array}{l}\text { 3.1. Degree of depreciation of the basic production assets (BPA) of the energy economy of the } \\
\text { region. } \\
\text { 3.2. The ratio of the average annual input of installed capacity and reconstruction of power plants in the } \\
\text { region over the previous } 5 \text {-year period to the established capacity of the region. }\end{array}$ \\
\hline
\end{tabular}

\section{Elements of the methodology for monitoring the state of Russia's ES at the regional level}

Methodology [3] uses two threshold values for each indicator. The pre-crisis threshold value of the indicator means the boundary value between the normal and pre-crisis state of energy sector in the aspect described by this indicator. The crisis threshold means, respectively, the boundary between the pre-crisis and crisis states. As a result of comparing the actual values of specific indicators with their thresholds, the level of crisis indicators is estimated. But in this case it is not possible to judge the crisis of the state of the region's ES in general. Some indicators may have acceptable from the ES's perspective; the values of others may be in a crisis or pre-crisis state. The picture can vary from region to region and from year to year. Accordingly, for the formation of a final qualitative assessment of the 
state of ES in the region, it is necessary to convolve qualitative assessments of the state of individual indicators in a single integrated assessment of the ES of the analysed territory. The state of an indicator, depending on the location of its values on the state scale, is estimated as follows:

$$
f\left(S_{i}\right)=\left\{\begin{array}{l}
\mathrm{N}, S_{i}<S_{i}^{P C} \\
P C, S_{i}^{P C} \leq S_{i}<S_{i}^{C} \quad i=1, n \\
C, S_{i} \geq S_{i}^{C}
\end{array}\right.
$$

where $n$-is the number of indicators being evaluated; $S i$ - actual (expected) value of the ith indicator; $S_{i}^{P C}, S_{i}^{C}-$ the pre-crisis and crisis threshold values of the $i$-th indicator; $N, P C$, $C$ - qualitative assessment of the state of energy sector in the aspect indicated by the $i$-th indicator: normal, pre-crisis and crisis, respectively.

Due to the fact that the indicators chosen for the assessment are not equal in their importance, an integral evaluation takes into account the significance of each specific indicator in their common set. Or "specific weights" of specific indicators in the overall system of their value. The specific weight of the indicator in the total sum of weights is determined by the equation:

$$
V_{i}=\sum_{j=1}^{n} v_{i j} / \sum_{i=1}^{n} \sum_{j=1}^{n} v_{i j}
$$

where $V_{i}$ - is the specific weight of the $i$-th indicator in the system of indicators being evaluated; $V_{\mathrm{i} j}$ - conditional significance of the $i$-th indicator in comparison with the $j$-th indicator.

In the course of the above described procedure, a qualitative assessment of the state of the ES of specific regions of Russia is formed:

$$
Q=\left\{\begin{array}{l}
N, \sum_{i=1}^{n} V_{i}^{N} \geq \delta_{N} \\
P C, \sum_{i=1}^{n} V_{i}^{N} \prec \delta_{N} u \sum_{i=1}^{n} V_{i}^{C} \prec \delta_{C}, i=1, n \\
C, \sum_{i=1}^{n} V_{i}^{C} \geq \delta_{C}
\end{array}\right.
$$

where $Q$ - an integral assessment of the qualitative state of the region's energy security; $V_{i}^{\mathbb{N}}$, $V_{i}^{E}$ - the specific weight of the $i$-th indicator, located in the area of normal and crisis values, respectively; $\delta_{\mathbb{N}}, \delta_{C}$ - coefficients that characterize the level of achievement of a normal or a crisis state, respectively. Carrying out such an assessment allows on the basis of monitoring the dynamic range of the integral indicator values, to understand in which direction the level of the ES of a particular region is changing and which region should be, directed attention from the level of the federal district or country first of all.

\section{Analysis of Russia's regions ES state}

In order to demonstrate the efficiency of the methodology discussed above, to highlight and assess some trends in the changing of the most important factors for ensuring the energy security of subjects located on the territory of the Russian Federation, the following steps were taken: 
- an information base has been created for all regions of Russia, based on statistical information [5-7];

- in the dynamics from 2012 to 2016 the values of all the indicators indicated in Table 1;

- the values of the ES indicators were quantitatively correlated with their threshold values corresponding to specially designated groups of territories;

- on the basis of expression (3), integral estimates of the state of ES in each of the analyzed regions were obtained.

As a result of the analysis of the obtained data on all subjects of the Russian Federation, we can get an idea of the trends in the situation with energy security. Based on the results of the analysis conducted in the dynamics from 2012 to 2016 in $80 \%$ of regions the situation from the point of view of ES has not changed radically and most regions of the Russian Federation are located in the area of crisis and pre-crisis state of ES.

We will dwell on the regions where the situation with ensuring the ES has changed qualitatively for the analyzed period, these regions are presented in Table 2.

In 2016, the crisis situation was noted in all regions of the Central Federal District, with the exception of the Lipetsk, Ryazan and Tula regions. In the Tula region (Table 2), the crisis situation shifted to the pre-crisis one due to the commissioning of capacities in 2013-2015 (at the Novomoskovskaya EPP $190 \mathrm{MW}$ and the start-up of two hydroelectric generators at Cherepetskaya EPP, with a capacity of $225 \mathrm{MW}$ each).

During the analyzed period, the situation improved in such regions as the Republic of Mari-el, the Republic of Tatarstan, the Kirov, Kurgan, Magadan regions and the Republic of Crimea. Improvement of the situation was due to the active policy on the renewal of BPA, the implementation of planned capital repairs in electricity and heat and power and made it possible to bring the situation in the regions into the region of pre-crisis values from the crisis. For example, in the Republic of Tatarstan, 590 MW of new generating capacities were commissioned in the last three years of the analyzed period (2014-2016).

Gas production in the republic increased almost threefold, which increased the ability to meet the needs in the primary energy from the region's own sources and switched to the range of normal values by the corresponding indicator (1.3) (Table 2). In the Republic of Crimea the situation is improving every year, due to the implementation of projects for the construction of generation facilities on the territory of the republic and the provision of reliable and uninterrupted power supply. The region has significant potential for the development of alternative energy sources, such as solar and wind. In 2014, a wind farm with a capacity of $25 \mathrm{MW}$ was commissioned, and in 2015-2016, commissioned four lines of energy bridge to connect the energy system of Crimea to the UES of Russia (UES South), with a total capacity of $800 \mathrm{MW}$.

However, at the same time, deterioration of power equipment on the peninsula is about $70 \%$, which requires appropriate attention and taking measures to reduce it. It is worth paying attention to those regions where the situation with ES has stabilized in six years, and by 2016 has moved into the region of acceptable values. There are only four such subjects ( $5 \%$ of the total number of analyzed): the Astrakhan Region, the Nizhny Novgorod Region, the Republic of Khakassia and the Trans-Baikal Territory. Conditions for improving the situation were: the modernization of electric power equipment, the annual introduction of new generating capacities and, as a consequence, the reduction of the share of a large source in the available electric power of the region (ID 2.2), as well as an increase in the ability to meet the needs in primary energy from the region's own sources.

Table 2. Assessment of the qualitative state of ES in selected regions of the Russian Federation 


\begin{tabular}{|c|c|c|c|c|c|c|c|c|c|c|c|c|}
\hline \multirow{4}{*}{ Year } & \multicolumn{8}{|c|}{$\begin{array}{c}\text { The order numbers of the estimated ES } \\
\text { indicators }\end{array}$} & \multirow{2}{*}{\multicolumn{3}{|c|}{$\begin{array}{c}\begin{array}{c}\text { Sum of densities } \\
\text { by state }\end{array} \\
\text { Boundaries of states } \\
\end{array}$}} & \multirow{4}{*}{$\begin{array}{c}\text { Quality } \\
\text { status of } \\
\text { ES }\end{array}$} \\
\hline & 1.1 & 1.2 & 1.3 & 2.1 & 2.2 & 2.3 & 3.1 & 3.2 & & & & \\
\hline & & & ecific & weig & s of $i$ & dicat & & & \multirow[b]{2}{*}{$C^{*}$} & \multirow[b]{2}{*}{ PC } & \multirow[b]{2}{*}{$\mathbf{N * *}$} & \\
\hline & $\begin{array}{l}\dot{J} \\
\stackrel{0}{0}\end{array}$ & 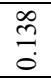 & $\stackrel{m}{\tilde{m}}$ & 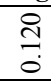 & $\begin{array}{l}\stackrel{9}{5} \\
0 \\
0\end{array}$ & $\stackrel{?}{\stackrel{P}{0}}$ & $\stackrel{\Im}{\beth}$ & $\frac{\grave{I}}{0}$ & & & & \\
\hline 1 & 2 & 3 & 4 & 5 & 6 & 7 & 8 & 9 & 10 & 11 & 12 & 13 \\
\hline \multicolumn{13}{|c|}{ Arhangelsk region } \\
\hline 2012 & $\mathrm{~N}$ & $\mathrm{~N}$ & $\mathrm{C}$ & $\mathrm{PC}$ & $\mathrm{N}$ & $\mathrm{C}$ & $\mathrm{PC}$ & $\mathrm{N}$ & 0.303 & 0.247 & 0.450 & $\mathrm{PC}$ \\
\hline 2016 & $\mathrm{~N}$ & $\mathrm{~N}$ & $\mathrm{C}$ & $\mathrm{PC}$ & $\mathrm{N}$ & $\mathrm{C}$ & $\mathrm{N}$ & $\mathrm{C}$ & 0.432 & 0.120 & 0.448 & $\mathrm{C}$ \\
\hline \multicolumn{13}{|c|}{ Tambov Region } \\
\hline 2012 & $\mathrm{~N}$ & $\mathrm{~N}$ & $\mathrm{C}$ & $\mathrm{C}$ & $\mathrm{PC}$ & $\mathrm{PC}$ & $\mathrm{C}$ & $\mathrm{PC}$ & 0.380 & 0.378 & 0.242 & $\mathrm{PC}$ \\
\hline 2016 & $\mathrm{~N}$ & $\mathrm{~N}$ & $\mathrm{C}$ & $\mathrm{C}$ & $\mathrm{PC}$ & $\mathrm{PC}$ & $\mathrm{C}$ & $\mathrm{C}$ & 0.509 & 0.249 & 0.242 & $\mathrm{C}$ \\
\hline \multicolumn{13}{|c|}{ Tula region } \\
\hline 2012 & $\mathrm{~N}$ & $\mathrm{~N}$ & $\mathrm{C}$ & $\mathrm{C}$ & $\mathrm{PC}$ & $\mathrm{PC}$ & $\mathrm{C}$ & $\mathrm{C}$ & 0.509 & 0.249 & 0.242 & $\mathrm{C}$ \\
\hline 2016 & $\mathrm{~N}$ & $\mathrm{~N}$ & $\mathrm{C}$ & $\mathrm{C}$ & $\mathrm{N}$ & $\mathrm{PC}$ & $\mathrm{PC}$ & $\mathrm{N}$ & 0.253 & 0.297 & 0.450 & $\mathrm{PC}$ \\
\hline \multicolumn{13}{|c|}{ Karachay-Cherkess Republic } \\
\hline 2012 & $\mathrm{~N}$ & $\mathrm{~N}$ & $\mathrm{C}$ & $\mathrm{C}$ & $\mathrm{N}$ & $\mathrm{N}$ & $\mathrm{N}$ & $\mathrm{N}$ & 0.253 & 0 & 0.747 & $\mathrm{~N}$ \\
\hline 2016 & $\mathrm{~N}$ & $\mathrm{~N}$ & $\mathrm{C}$ & $\mathrm{C}$ & $\mathrm{N}$ & $\mathrm{N}$ & $\mathrm{N}$ & $\mathrm{PC}$ & 0.253 & 0.129 & 0.618 & $\mathrm{PC}$ \\
\hline \multicolumn{13}{|c|}{ Astrakhan Region } \\
\hline 2012 & $\mathrm{~N}$ & $\mathrm{~N}$ & $\mathrm{~N}$ & $\mathrm{~N}$ & PC & $\mathrm{N}$ & $\mathrm{PC}$ & $\mathrm{C}$ & 0.129 & 0.206 & 0.665 & $\mathrm{PC}$ \\
\hline 2016 & $\mathrm{~N}$ & $\mathrm{~N}$ & $\mathrm{~N}$ & $\mathrm{~N}$ & $\mathrm{PC}$ & $\mathrm{N}$ & $\mathrm{PC}$ & $\mathrm{N}$ & 0 & 0.206 & 0.794 & $\mathrm{~N}$ \\
\hline \multicolumn{13}{|c|}{ Mari El Republic } \\
\hline 2012 & $\mathrm{~N}$ & $\mathrm{~N}$ & $\mathrm{PC}$ & C & $\mathrm{N}$ & $\mathrm{C}$ & $\mathrm{PC}$ & $\mathrm{C}$ & 0.419 & 0.26 & 0.321 & C \\
\hline 2016 & $\mathrm{~N}$ & $\mathrm{~N}$ & $\mathrm{~N}$ & $\mathrm{C}$ & $\mathrm{N}$ & $\mathrm{C}$ & $\mathrm{PC}$ & $\mathrm{N}$ & 0.29 & 0.127 & 0.583 & $\mathrm{PC}$ \\
\hline \multicolumn{13}{|c|}{ Republic of Tatarstan } \\
\hline 2012 & $\mathrm{~N}$ & $\mathrm{~N}$ & $\mathrm{PC}$ & $\mathrm{C}$ & $\mathrm{N}$ & $\mathrm{C}$ & $\mathrm{PC}$ & $\mathrm{C}$ & 0.419 & 0.26 & 0.321 & $\mathrm{C}$ \\
\hline 2016 & $\mathrm{~N}$ & $\mathrm{~N}$ & $\mathrm{~N}$ & C & $\mathrm{N}$ & C & PC & $\mathrm{PC}$ & 0.29 & 0.256 & 0.454 & PC \\
\hline \multicolumn{13}{|c|}{ Kirov region } \\
\hline 2012 & $\mathrm{~N}$ & $\mathrm{~N}$ & $\mathrm{C}$ & $\mathrm{C}$ & $\mathrm{N}$ & $\mathrm{N}$ & $\mathrm{C}$ & $\mathrm{C}$ & 0.509 & 0 & 0.491 & C \\
\hline 2016 & $\mathrm{~N}$ & $\mathrm{~N}$ & $\mathrm{C}$ & $\mathrm{C}$ & $\mathrm{N}$ & $\mathrm{N}$ & $\mathrm{C}$ & $\mathrm{N}$ & 0.38 & 0 & 0.62 & $\mathrm{PC}$ \\
\hline \multicolumn{13}{|c|}{ Nizhny Novgorod Region } \\
\hline 2012 & $\mathrm{~N}$ & $\mathrm{~N}$ & $\mathrm{~N}$ & $\mathrm{C}$ & $\mathrm{N}$ & $\mathrm{N}$ & $\mathrm{PC}$ & $\mathrm{C}$ & 0.249 & 0.127 & 0.624 & $\mathrm{PC}$ \\
\hline 2016 & $\mathrm{~N}$ & $\mathrm{~N}$ & $\mathrm{~N}$ & $\mathrm{C}$ & $\mathrm{N}$ & $\mathrm{N}$ & $\mathrm{PC}$ & $\mathrm{N}$ & 0.12 & 0 & 0.88 & $\mathrm{~N}$ \\
\hline \multicolumn{13}{|c|}{ Kurgan region } \\
\hline 2012 & $\mathrm{~N}$ & $\mathrm{~N}$ & $\mathrm{C}$ & $\mathrm{C}$ & $\mathrm{C}$ & $\mathrm{N}$ & $\mathrm{C}$ & $\mathrm{C}$ & 0.588 & 0 & 0.412 & $\mathrm{C}$ \\
\hline 2016 & $\mathrm{~N}$ & $\mathrm{~N}$ & $\mathrm{C}$ & $\mathrm{C}$ & $\mathrm{PC}$ & $\mathrm{N}$ & $\mathrm{PC}$ & $\mathrm{N}$ & 0.253 & 0.206 & 0.541 & $\mathrm{PC}$ \\
\hline \multicolumn{13}{|c|}{ The Republic of Khakassia } \\
\hline 2012 & $\mathrm{~N}$ & $\mathrm{~N}$ & $\mathrm{~N}$ & $\mathrm{PC}$ & $\mathrm{C}$ & $\mathrm{N}$ & $\mathrm{PC}$ & $\mathrm{N}$ & 0.079 & 0.247 & 0.674 & $\mathrm{PC}$ \\
\hline 2016 & $\mathrm{~N}$ & $\mathrm{~N}$ & $\mathrm{~N}$ & $\mathrm{PC}$ & $\mathrm{C}$ & $\mathrm{N}$ & $\mathrm{N}$ & $\mathrm{N}$ & 0.079 & 0.12 & 0.801 & $\mathrm{~N}$ \\
\hline \multicolumn{13}{|c|}{ Transbaikal region } \\
\hline 2012 & PC & $\mathrm{PC}$ & $\mathrm{N}$ & PC & PC & $\mathrm{N}$ & $\mathrm{PC}$ & $\mathrm{C}$ & 0.129 & 0.568 & 0.303 & PC \\
\hline 2016 & $\mathrm{~N}$ & $\mathrm{~N}$ & $\mathrm{~N}$ & $\mathrm{PC}$ & $\mathrm{N}$ & $\mathrm{N}$ & $\mathrm{PC}$ & $\mathrm{N}$ & 0 & 0.247 & 0.753 & $\mathrm{~N}$ \\
\hline & & & & & & & $\operatorname{adan}$ & egio & & & & \\
\hline 2012 & $\mathrm{~N}$ & $\mathrm{~N}$ & $\mathrm{C}$ & $\mathrm{C}$ & $\mathrm{C}$ & $\mathrm{N}$ & $\mathrm{PC}$ & $\mathrm{C}$ & 0.461 & 0.127 & 0.412 & $\mathrm{C}$ \\
\hline 2016 & $\mathrm{~N}$ & $\mathrm{~N}$ & $\mathrm{PC}$ & $\mathrm{C}$ & $\mathrm{C}$ & $\mathrm{N}$ & $\mathrm{PC}$ & $\mathrm{C}$ & 0.328 & 0.26 & 0.412 & $\mathrm{PC}$ \\
\hline & & & & & & Rep & olic 0 & Crim & & & & \\
\hline 2012 & $\mathrm{C}$ & $\mathrm{N}$ & $\mathrm{C}$ & $\mathrm{C}$ & $\mathrm{N}$ & $\mathrm{N}$ & $\mathrm{PC}$ & $\mathrm{C}$ & 0.486 & 0.127 & 0.387 & $\mathrm{C}$ \\
\hline 2016 & $\mathrm{C}$ & $\mathrm{N}$ & $\mathrm{C}$ & $\mathrm{C}$ & $\mathrm{N}$ & $\mathrm{N}$ & $\mathrm{PC}$ & $\mathrm{N}$ & 0.357 & 0.127 & 0.516 & $\mathrm{PC}$ \\
\hline
\end{tabular}

Note: *The state of ES in the region is recognized as a crisis if the sum of the specific weights of the indicators in state " $\mathrm{C}$ " (crisis) exceeds 0,$4 ; * *$ The state of ES in the region is recognized as normal if the sum of the specific weights of indicators in the state " $\mathrm{N}$ " (normal) exceeds 0,7 
In order to identify trends in changing the state of energy security of regions by individual indicators, we will analyze the change in their state from 2012 to 2016 . In Table 3 as a percentage, the qualitative states of the various indicators are presented in 2012 and 2016.

Table 3. Structure of the crisis in the indicators of energy security in the regions and the assessment of the state of the ES regions of Russia by indicators $(2012,2016), \%$.

\begin{tabular}{|c|c|c|c|c|}
\hline \multirow{2}{*}{ Indicator ES } & \multicolumn{4}{|c|}{ Status of the indicator by region } \\
\cline { 2 - 5 } & Year & $\mathbf{N}^{*}$ & $\mathbf{P C}$ & $\mathbf{C}^{* *}$ \\
\hline \multirow{3}{*}{1.1} & 2012 & 79 & 5 & 16 \\
\cline { 2 - 5 } & 2016 & 79 & 4 & 17 \\
\hline \multirow{2}{*}{1.2} & 2012 & 90 & 5 & 5 \\
\cline { 2 - 5 } & 2016 & 92 & 4 & 4 \\
\hline \multirow{2}{*}{1.3} & 2012 & 34 & 9 & 57 \\
\cline { 2 - 5 } & 2016 & 36 & 9 & 55 \\
\hline \multirow{2}{*}{2.1} & 2012 & 18 & 17 & 65 \\
\cline { 2 - 5 } & 2016 & 13 & 18 & 69 \\
\hline \multirow{2}{*}{2.2} & 2012 & 49 & 25 & 26 \\
\cline { 2 - 5 } & 2016 & 53 & 20 & 27 \\
\hline \multirow{2}{*}{3.3} & 2012 & 57 & 16 & 27 \\
\cline { 2 - 5 } & 2016 & 56 & 17 & 27 \\
\cline { 2 - 5 } & 2012 & 6 & 72 & 22 \\
\hline \multirow{2}{*}{3.2} & 2016 & 10 & 70 & 20 \\
\cline { 2 - 5 } & 2012 & 35 & 17 & 48 \\
\hline
\end{tabular}

Note: * The state of ES in the region is recognized as normal if the sum of the specific weights of indicators in the state "N" (normal) exceeds 0,$7 ;{ }^{* *}$ The state of ES in the region is recognized as a crisis if the sum of the specific weights of the indicators in state "C" (crisis) exceeds 0,4

Based on the comparative analysis and data generated in Table. 3, the following results were obtained. The situation in the regions has changed slightly over the six-year period by indicators: 1.1 (The ratio of the total available capacity of the region's power plants to the maximum electric load of consumers in its territory), 1.2 (The ratio of the amount of available capacity of power plants and the interconnection capacity of the region with neighboring consumers to the maximum electric load its territory), 1.3 (Possibilities for meeting the needs in the primary energy from the region's own sources) and 2.3 (Level of potential provision concern fuel demand given the sharp cooling $(10 \%$ impingement consumption) in the region). The situation with the share of the dominant resource in the total consumption of the region's primary energy deteriorated by $5 \%$ (indicator 2.1 ). These include all regions of the Central, North Caucasian, Volga Federal Districts, as well as the Kaliningrad, Leningrad, Murmansk, Novgorod and Pskov regions of the North-West Federal District, which do not have sufficient sources of their own for the production of primary energy, and the dominant type of fuel consumption in which is the gas. According to indicator 2.2 (Share of the largest power plant in the installed electric capacity of the region), the situation as a whole, across the country, has improved. By $5 \%$ due to commissioning of new capacities. This, along with the repairs carried out, tended to slightly improve the situation with indicators 3.1 (Degree of depreciation of the energy sector in the region) - by $4 \%$ and 3.2 (The ratio of the average annual input of installed capacity and reconstruction of power plants in the region over the last 5 -year period to the established capacity of the region) - by $11 \%$. Although at the same time, in all regions of the Russian Federation, the current values of the degree of run out of equipment are $50-60 \%$, and the situation requires constant attention. 


\section{Conclusions}

In general, most of the regions are located in the area of crisis and pre-crisis values of indicator weights.

It can be noted that a relatively high percentage of regions with an acceptable state of ES according to the indicator 1.2 (The ratio of the sum of the available capacity of power plants and the capacity of interconnections of the region with neighboring to the maximum electric load of consumers in its territory) is $92 \%$ and 1.1 (The ratio of total the available capacity of the region's power plants to the maximum electric load of consumers on its territory) $-79 \%$ of the regions.

The pre-crisis situation in $70 \%$ of the regions, according to Table 3 , is affected by the unsatisfactory state of indicator 3.1 - the degree of depreciation of the basic production assets of the energy sector in the region. As in the majority of the subjects of the Russian Federation the current values of the degree of wear of the equipment are 50-60\%.

\section{References}

1. V. Bushuyev, N. Voropai, A. Masterpanov, Yu. Shafranik. Energy security of Russia, (1998)

2. N. Pyatkova, S. Senderov, M. Cheltsov. Application of a two-level technology for research in solving energy security problems, Izvestiya RAN, Power Engineering, 6, pp. 31-39,(2000)

3. S. Senderov, N. Pyatkova, V. Rabchuk, G. Slavin, S. Vorobev, E. Smirnova. Methodology for monitoring the state of energy security of Russia at the regional level, (2014)

4. Statistical form of Rosstat, Information on balances, receipt and consumption of fuel and heat, collection and use of used oil products (2012-2016)

5. Statistical form of Rosstat, Information on the use of fuel and energy resources (20122016)

6. Statistical form of Rosstat, Technical and economic indicators of power plants, district boilers (2011-2016) 